\title{
Private International Law
}

\section{Offshore trusts and companies}

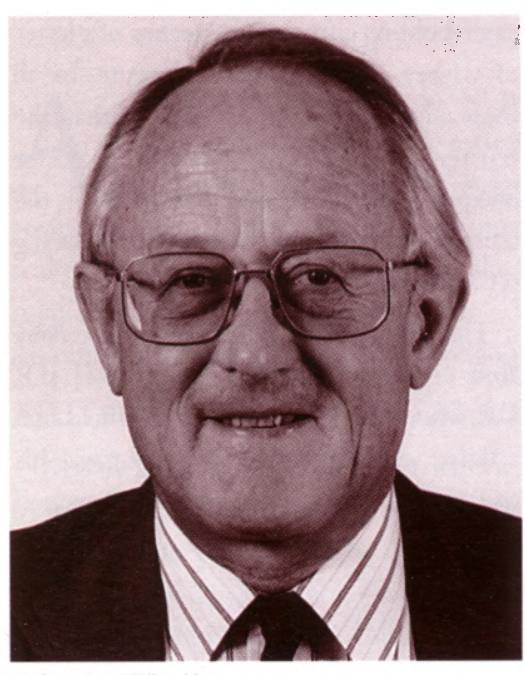

Professor Peter Willoughby

The subject of offshore trusts and companies is assumed by some to be largely concerned with tax avoidance or, worse still, money laundering. There are, however, many reasons for establishing offshore trusts and company structures which are entirely reputable. Before considering the reasons for establishing offshore trusts and companies, it is necessary to say a little about the meaning of 'offshore'.

\section{WHAT IS OFFSHORE}

It is not for politicians and journalists to attack offshore financial centres on the grounds that they are in some way undermining their own onshore society. Allegations are often made that offshore jurisdictions are unregulated and live off tax evasion, tax avoidance and money laundering. While there have been and still are some offshore jurisdictions which lack proper regulation, there are many others which are rather better regulated in some respects than, for example, the UK.

Moreover, the UK, when offshore to someone who is onshore somewhere else, can be an excellent tax haven. In this connection it should not be forgotten that while wealthy Arabs in Knightsbridge and wealthy Swedes in Weybridge may pay little UK income tax, they do spend large sums of money and pay a lot of VAT and stamp duty when they purchase their UK homes and pay council tax. Therefore they do contribute significantly to the UK economy.

With regard to regulation, it is salutary

\section{by Professor Peter Willoughby}

to note that whereas the financial scandals involving Barlow Clowes and BCCI caused very serious problems in the UK, these two organisations were excluded from Jersey, Guernsey and Alderney. It is therefore salutary to remember that offshore is no more than where one is not, and before criticising other jurisdictions, be they large or small, thought should be given to the way in which ones own onshore jurisdiction is regulated and whether it can be used as a tax haven for avoiding the taxes of another jurisdiction.

If a resident and domiciled British subject wishes to incorporate a company in, say, Alderney, Bermuda, Guernsey or Jersey, the application has to be vetted by the authorities in those jurisdictions to check the good faith and track record of the future beneficial owner before the incorporation can proceed. Not surprisingly, this is not good for some forms of business but these jurisdictions do not want to attract business at any price. In contrast, there is no similar restriction on the incorporation of companies in England and Wales, or Scotland.

\section{REASONS FOR ESTABLISHING OFFSHORE TRUSTS}

There are many reasons why people might wish to establish offshore trusts and to use asset-holding offshore companies as part of a structure. For those not involved with offshore jurisdictions, the reason which springs instantly to mind is tax planning of some kind. This is, however, by no means the only, or indeed the most important, reason for setting up an offshore trust or using an offshore company. The main reasons for establishing offshore trusts are asset planning in the way that a wealthy individual (and not his home government) wishes to deal with his assets, providing for continuity after death, providing for minors and those with disabilities, and confidentiality.

Where tax mitigation is undertaken, this is often not the main purpose of the trust but involves the carrying out of the purpose of the trust in the least taxexpensive way. To this list of well-known reasons for setting up offshore trusts should be added the more controversial reason of asset protection, more accurately, protecting debtors from actual or potential creditors. Most reputable offshore jurisdictions have not enacted designer legislation to attract debtors who require protection from creditors. It is regrettable, however, that a few jurisdictions have done this but so far with mixed results (for example see 515 Orange Grove Owners Association v Orange Grove Partners (No. I) (1995) No. 208/94 Cook Islands Court of Appeal).

It will be said by some that most, if not all, of those objectives can be obtained by onshore trusts. To some extent this is true. However, those who have suffered under harsh and undemocratic regimes understandably wish to place their assets, in confidence, under the control of a trustee in a more favourable jurisdiction. There are also those who come from democratic regimes but have suffered from very high rates of taxation and who simply do not wish to run the risk of incurring substantial tax assessments in the future, even though their home jurisdictions are not at present engaging in fiscal confiscation.

\section{MISGUIDED ACCUSATION}

Allegations are often made that offshore jurisdictions are unregulated and live off tax evasion, tax avoidance and money laundering. While there have been and still are some offshore jurisdictions which lack proper regulation, there are many others which are rather better regulated in some respects than, for example, the UK.

There is yet another reason. Many offshore jurisdictions have developed trust laws which modify, and in some cases improve upon, the traditional principles of equity and statutory rules in jurisdictions such as England and Wales. For example, rules against perpetuity and accumulations are sometimes amended or abolished. Provision is sometimes made to permit purpose trusts; uncertainty as to whether or not the 
proper law of a trust can be changed is often clarified; trustees' powers of delegation can be increased; protection may be given against the rules of forced heirship which apply in the home jurisdiction of the settlor; and strict statutory rules may be provided to restrict the power to exclude trustees from liability for gross negligence. In the latter regard, the law is stricter in say, Jersey, than it is in England and Wales.

\section{INTERNATIONAL ESTATE PLANNING}

In the modern world where so many entrepreneurs operate globally, perhaps in a dozen or more countries, it is meaningless to talk of offshore trusts. Offshore to whom and to what one might ask? What the entrepreneur needs to ensure is continuity after his death with a minimum of disruption to his various businesses and, most importantly to his dependants, using an asset-holding structure which can avoid the slow, expensive, bureaucratic and public procedure of probate spread over a number of jurisdictions.

For example, suppose that we have an engineer who is a British subject but who has lived in Hong Kong for 30 years. He is married to a Chinese lady and his permanent home is in Hong Kong. For many years the engineer has designed electrical appliances for domestic use together with the factory tooling for manufacturing these appliances. His wife works with him in the business as a codirector and they own various factories through shareholdings in companies which are incorporated in Hong Kong, South China, Mexico, Chile, Finland, Ireland and Italy.

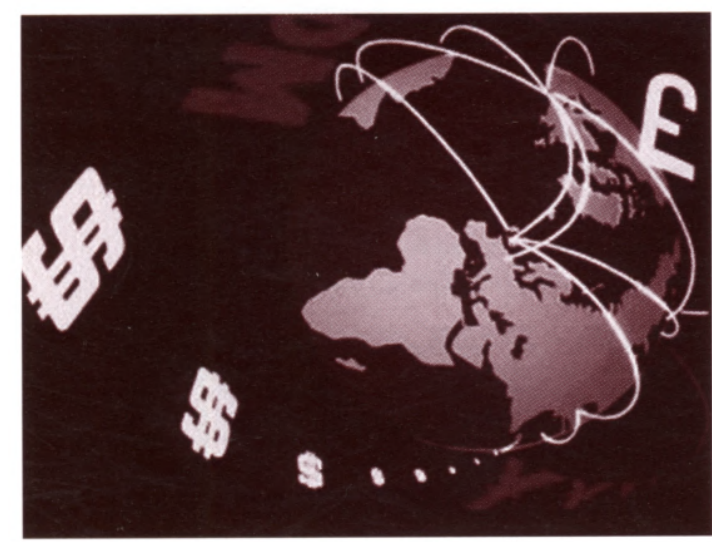

When one of the directors dies, the winding up of their respective estates will be slow and expensive. There will be to the surviving dependants as the succession laws and procedures of seven jurisdictions are applied. The best solution in this sort of case is to provide for a discretionary trust in a jurisdiction with a sensible modern trust law which is administered by an experienced, skilled and reliable trust company.

The trust will own substantial shareholdings in the various companies with the result that, on the death of the engineer or his wife, their interests as discretionary beneficiaries will cease but the companies will continue to be run by the surviving members of the family without any need to obtain probate of the trust assets in the jurisdictions involved.

The engineer and his wife will not, in all probability, have transferred all their assets to the trust but, sensibly, will have continued to hold some personal assets in the jurisdictions with which they have the most active connections. They will probably dispose of these assets by means of a will or wills appropriate to the jurisdictions in question. To this sort of planning there will usually be added provision in the trust deed designed to prevent the next generation from selling off the family business, other than in certain specified circumstances. The question of tax planning will probably arise after the basic structure has been agreed. The tax planning will then be an attempt in each of the jurisdictions to ensure that tax is not paid where it can be legally mitigated or avoided.

\section{FUNDAMENTAL PROBLEMS}

There are inevitable difficulties with the kind of planning outlined above, but by and large these do not concern taxation. The main difficulties are likely to be more fundamental. The first is that some of the jurisdictions may have civil law systems which do not recognise the concept of the trust, although they will normally recognise the companies of another jurisdiction. Some of these jurisdictions may also provide for the forced heirship of a proportion of a deceased person's assets and, as a result, the trust may not in practice be effective with regard to the assets in such a jurisdiction.

Another problem is that a traditional trust requires control, and usually ownership, of the trust assets to be in the hands of the trustees and not the settlor. Many settlors are, however, reluctant to relinquish control over their assets to trustees and in practice try to retain a considerable degree of control.

Sometimes this control is exercised directly with the result that the trustecs are little more than nominees and sometimes the control is exercised indirectly through a controlling or sole directorship of an asset-holding company, by means of a letter of wishes or through a protector. In all these situations, if the effect is that the trustee does not in practice exercise adequate discretion and control over the trust assets, the trust is in danger of being set aside as a sham if challenged.

The leading case is Rahman ${ }_{v}$ Chase Bank Trust Company (CI) Ltd \& Ors [1991] JLR 103 where the Jersey Royal Court held that a trust, which the settlor thought was his will and in respect of which he exercised

\section{VARIED MOTIVES}

There are many reasons why people might wish to establish offshore trusts and to use asset-holding offshore companies as part of a structure. For those not involved with offshore jurisdictions, the reason which springs instantly to mind is tax planning of some kind. This is, however, by no means the only, or indeed the most important, reason for setting up an offshore trust or using an offshore company.

total control over the trust assets, was held to be void as a sham.

\section{CONCLUSION}

There are many offshore trusts with asset-holding offshore companies which have been established for perfectly proper reasons that are not in any way improper or anti-social. Before criticising trustees' services offered in offshore jurisdictions, politicians and journalists should distinguish carefully between those offshore jurisdictions which have a long history of reputable and democratic government and which are providing well-regulated services not available in larger jurisdictions and those, usually newer jurisdictions which, in an effort to attract any business, do not set high standards.

\footnotetext{
Professor Peter Willoughby

Deacon Graham \&James

Hong Kong
} 